\title{
REGIONÁLIS MULTIPLIKÁCIÓ ÉS EGY ALKALMAZÁSA
}

\author{
Dr. PhD. Kotosz Balázs ${ }^{1}$ \\ ' föiskolai docens, Szegedi Tudományegyetem, Mérnöki Kar
}

\section{SUMMARY}

The export base theory is really based on the regional multiplicator theory of international economy. In the paper, we step over the usual textbook examples and show how the multiplicator can be less than one, practically decreasing local income. We also analyze a special multiplication process, in particular the role of higher education institutions. The impact of higher education institution on local economy is extensively wide. Universities have important impact on the input and the output side, or on the demand and supply side, also. Beck et al (1995) define economic impact as ,the difference between existing economic activity in a region given the presence of the institution and the level that would have been present if the institution did not exist." There are many approaches of the analysis of the regional impacts, the most important and most widely used is the Keynesian multiplicator approach.

Kulcsszavak: gazdasági hatás, regionális multiplikátor, keynesi modell

\section{BEVEZETÉS}

Az export bázis elmélet fogalmazza meg a regionális multiplikáció alapjául szolgáló modellt. A tanulmány elsö részében bemutatjuk, hogy ez a multiplikációs folyamat hogyan müködik különböző körülmények között és felhívjuk a figyelmet azokra a hatásokra, amelyek a tankönyvi példákon túlmutatva a gyakorlatot jobban leírják. Végső soron eljuthatunk egy olyan - nem irreális - állapotig, ahol a gazdaság húzóerejének számító szektor nem növeli, hanem éppen csökkenti a régió jövedelmét. Ezután egy speciális multiplikációs folyamatot veszünk górcső alá, a felsöoktatási intézmények gazdasági szerepét. A nagy egyetemvárosok tudásközponti szerepe közismert, azonban fontos gazdasági hatásai is vannak a felsöoktatás jelenlétének egy településen. Beck (1995) definíciója szerint a gazdasági hatás az a különbség „a gazdasági tevékenységben, amely az adott intézmény(ek) jelenlétében, illetve annak hiányában figyelhetö meg". A meglehetősen összetett és sokrétü modellezés folyamatát (elmélet és a szükséges adatbázisok, számitások) és az eddig ismert hazai eredményeket foglaljuk össze. A továbbiakban a felsőoktatási intézmény és az egyetem kifejezéseket szinonimaként használjuk, mert modellünk szempontjából az intézmény belső szervezete és az oktatás szintje irreleváns.

\section{AZ EXPORT BẢZIS ELMÉLET ÉS A REGIONÁLIS MULTIPLIKÁTOR}

Az export bázis elmélet egy keynesi típusú makrogazdasági modell továbbfejlesztése, nyitott gazdaságot feltételezve. A modell eredetileg a nemzetgazdaság egészére készült, később fedezte fel a regionális gazdaságtan és alkalmazta regionális és helyi szintü problémák elemzésére is.

A gazdaságot alapvetően két szektorra osztjuk (Id. 1. ábra), egy export szektorra, amely alapvetően exportra termel, és egy helyi szektorra, amely a helyi szükségleteket elégiti ki. A szektorok meghatározása nemzetgazdasági szinten egyértelmủ lehet, de regionális vagy helyi szinten már nem egyértelmủ. A régió határának meghúzása az eredmények szempontjából lényeges lehet, ezért a gyakorlati munka során érdemes több lehetőséget is elemezni, érzékenységvizsgálatokat lefolytatni. Az egyetemek hatáselemzése során az egyetem lesz a kiemelten kezelt ,szektor”. 
1. ábra: Az export-bázis elmélet szektorai

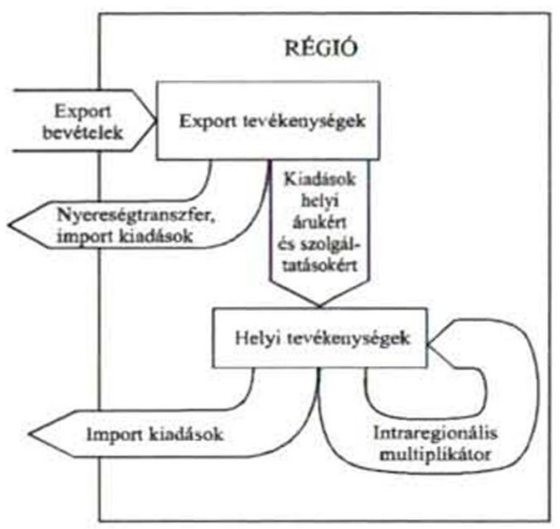

Forrás: Lengyel-Rechnitzer, 2004.

A keynesi modell bal oldalán (1) a jövedelem (Y), a jobb oldalon a kereslet elemei: C a fogyasztás, I a beruházás, $\mathrm{X}$ az export, $\mathrm{M}$ az import. A hasonló modellekben szereplö kormányzati kiadásokat és adókat az egyszerűség kedvéért nem szerepeltetjük.

$$
Y=C+I+X-M
$$

Standard fogyasztási függvénnyel dolgozunk:

$$
C=c_{0}+c Y
$$

$\mathrm{Az}$ importot hasonlóan a jövedelem függvényében írjuk fel (ezzel lényegében azt feltételezzük, hogy az import kizárólag fogyasztási célokat szolgál), továbbá feltételezzük, hogy a fogyasztási határhajlandóság (c) nem kisebb az import kiadási határhajlandóságnál.

$$
M=m_{0}+m Y
$$

I és $\mathrm{X}$ egzogén:

$$
I=\bar{I} \text { és } X=\bar{X} \text {. }
$$

Behelyettesitve (1)-be, azt kapjuk, hogy:

$$
Y=c_{0}+c Y+\bar{I}+\bar{X}-m_{0}-m Y
$$

ebből kifejezve a jövedelmet:

$$
Y=\frac{c_{0}-m_{0}+\bar{I}+\bar{X}}{(1-c+m)}
$$


Ebböl a formából már könnyen kifejezhető a regionális multiplikátor (amely egységnyi export növekedés hatását mutatja a régió egyensúlyi jövedelmére):

$$
\frac{\partial Y}{\partial \bar{X}}=\frac{1}{(1-c+m)}=\frac{1}{1-(c-m)}
$$

Amennyiben az állam jövedelemarányos adót vezet be (adókulcs $t: 0 \leq t \leq 1$ ), akkor a (2) egyenlet jobb oldalán a jövedelem helyébe a rendelkezésre álló (adózás utáni) jövedelem kerül. Így

$$
\frac{\partial Y}{\partial \bar{X}}=\frac{1}{1-(c-m)(1-t)}
$$

Látható, hogy az adózást is feltételező regionális multiplikátor kisebb az adózás nélküli multiplikátornál.

Amennyiben feltételezzük, hogy az exportra termelés közvetlenül importot tesz szükségessé (azaz az exportnak jelentős az importtartalma, ami Magyarország legjelentősebb - jellemzően autóipari - exportörei esetén teljesül), akkor az import függvénye már megváltozik:

$$
M=m_{0}+m Y+m_{X} \bar{X} \quad \text { ahol }\left(\bar{X}-m_{X} \bar{X}\right) \text { a nettó export. }
$$

A (2) egyenlet helyébe a következö lép:

$$
Y=c_{0}+c Y+\bar{I}+\bar{X}-m_{0}-m Y-m_{X} \bar{X}
$$

Kifejezve a jövedelmet, majd kiemelve a regionális multiplikátort:

$$
\begin{aligned}
& Y=\frac{c_{0}-m_{0}+\bar{I}+\left(1-m_{l}\right) \bar{X}}{(1-c+m)} \\
& \frac{\partial Y}{\partial \bar{X}}=\frac{\left(1-m_{X}\right)}{(1-c+m)}
\end{aligned}
$$

Az így kapott multiplikátor kisebb az egyszerü multiplikátornál, minél magasabb az export importtartalma, annál alacsonyabb. Alacsony hazai fogyasztási határhajlandóság és magas importtartalom esetén értéke akár 1-nél kisebb is lehet, azaz elöfordulhat, hogy az export ágazat még saját teljesítményével sem növeli a regionális gazdaság jövedelmét.

A valós helyzethez közelitve feltételezhetjük, hogy az export ágazat egy része $\left(m_{F}\right)$ külföldi (régión kívüli) tulajdonban van, akik a nyereséget (vagy annak egy részét) kivonják a vállalatból és az országon (régión) kívül jelenik meg jövedelemként. A feltevés a magyar gazdaságra is helytálló. Tegyük fel, hogy a külföldiek jövedelmüket a hazaiaknak megfelelő arányban $(c-m)$ költik el belföldön (a régión belül), a többit külföldön (a régión kívül). Ez a helyi gazdaság újabb megcsapolása. A modell következö lépésében azt feltételezzük, hogy a külföldi tulajdonosok a jövedelmük egészét kivonják és az országon (régión) kívül költik el. 
Így a (6) egyenlet kiegészül:

$$
Y=c_{0}+c Y+\bar{I}+\bar{X}-m_{0}-m Y-m_{X} \bar{X}-m_{F}\left(\bar{X}-m_{X} \bar{X}\right)
$$

Ebböl:

$$
Y=\frac{c_{0}-m_{0}+\bar{I}+\left(1-m_{X}-m_{F}+m_{X} m_{F}\right) \bar{X}}{(1-c+m)},
$$

a regionális multiplikátor pedig

$$
\frac{\partial Y}{\partial \bar{X}}=\frac{\left(1-m_{X}-m_{F}+m_{X} m_{F}\right)}{(1-c+m)}
$$

Amennyiben az állam továbbra is csak a jövedelmet adóztatja $t$ kulccsal, akkor a multiplikátor:

$$
\frac{\partial Y}{\partial \bar{X}}=\frac{\left(1-m_{X}-m_{F}+m_{X} m_{F}\right)}{1-(c-m)(1-t)}
$$

A multiplikátorok értékeiről áttekintést nyújt az 1. táblázat.

1. táblázat: A regionális multiplikátor néhány értéke

\begin{tabular}{|r|r|r|r|r|r|}
\hline \multicolumn{1}{c|}{$c$} & \multicolumn{1}{c|}{$m$} & \multicolumn{1}{c|}{$t$} & $m_{X}$ & $m_{F}$ & $\frac{\partial Y}{\partial \bar{X}}$ \\
\hline 0,8 & 0 & 0 & 0 & 0 & 5,00 \\
\hline 0,7 & 0 & 0 & 0 & 0 & 3,33 \\
\hline 0,7 & 0,2 & 0 & 0 & 0 & 2,00 \\
\hline 0,7 & 0,4 & 0 & 0 & 0 & 1,43 \\
\hline 0,7 & 0,4 & 0,2 & 0 & 0 & 1,32 \\
\hline 0,7 & 0,4 & 0,36 & 0 & 0 & 1,24 \\
\hline 0,7 & 0 & 0 & 0,2 & 0 & 2,67 \\
\hline 0,7 & 0,4 & 0 & 0,2 & 0 & 1,14 \\
\hline 0,7 & 0,4 & 0,36 & 0,2 & 0 & 0,99 \\
\hline 0,7 & 0,4 & 0,36 & 0,7 & 0 & 0,37 \\
\hline 0,7 & 0,4 & 0,36 & 0,7 & 0,2 & 0,30 \\
\hline 0,7 & 0,4 & 0,36 & 0,7 & 0,5 & 0,19 \\
\hline 0,7 & 0,4 & 0,36 & 0,7 & 0,7 & 0,11 \\
\hline
\end{tabular}

Forrás: A szerző saját szerkesztése

Ahogy az 1. táblázatban látható, a hagyományos keynesi multiplikátor értéke jóval nagyobb 1-nél, az exportnak (mint bármely más autonóm keresleti elemnek) jelentős többszöröző hatása van a régió jövedelmére. Az import fogyasztás megengedése (ami export feltételezése esetén reális) jelentősen csökkenti a multiplikátor értékét. Az adózás bevezetése további csökkenést eredményez, de a multiplikátor értéke még tetszés szerinti paraméterkombinációk mellett sem lehet 1-nél kisebb (azaz legalább az export értékével nő a régió jövedelme). Amennyiben megengedjük az exportjövedelem közvetlen kiáramlását (az export 
importtartalmán vagy a kiszivárgó nyereség formájában), a multiplikátor jellemzően 1-nél kisebb lesz. Ha jelentős importhányadot feltételezünk (a magyar gazdaságra Csávás et al, 2006 ezt 0,7 körüli értékre becsülte), már önmagában 0,3-0,4 körüli értékre csökkenti a „sokszorozó" hatást, ha ehhez még jelentős külföldi tulajdoni hányadot is felteszünk, jellemzően 0,1 körüli multiplikátorral kell számolni.

\section{A MODELLEZÉS ADATIGÉNYE}

A felsőoktatási intézmények vizsgálata során a (9) egyenlet egyes elemeit kell megbecsülni.

A fogyasztási függvény becslésére egyfelöl - amennyiben rendelkezésre áll - helyi vagy regionális makrostatisztikákat lehet felhasználni, de az egyetem lokális koncentráltsága miatt kérdöives vizsgálatok is nagyban segíthetik a becslést. A fogyasztási határhajlandóságot mind makroszinten, mind a korábbi - kifejezetten egyetemi - hatásvizsgálatok 0,7-0,8 körüli értéknek találták (Dusek, 2003).

A fogyasztásban az import arányára már nehezebb becslést adni. Amennyiben valóban helyi szinten kívánunk dolgozni, akkor csak a helyben elköltött jövedelem arányából tudunk kiindulni, amit szintén - az elözővel akár összekapcsolt - felmérésből tudhatunk meg. Országos szinten az export importarányából és a külkereskedelmi nyitottság mutatóiból becsülhetỏ ez az érték. A kétféle megközelités (mivel más területi egységre és fogyasztásra vonatkozik) eltérő eredményeket szolgál, míg a makroszintü értékek 0,4 körüli értéket adnak, addig a helyi felmérések 0,2 körüli eredményt produkálnak.

Az egyetem beruházási tevékenysége a költségvetésböl kiolvasható.

Problémásabb az egyetem exportjának meghatározása, azaz, hogy mekkora értéket állít elö ez az ágazat. Florax (1992) vagy Garrido-Iserte és Galoo-Rivera (1995), továbbá Huggins és Cook (1997), illetve Brown és Heaney (1997) több szempontú áttekintést adnak a lehatárolásról. Kifejezetten a gazdasági output kérdésével foglalkozik Pallenbarg (2005), Johnson (1994) és Bleaney et al (1992). Az utóbbi a korábbiakban levezetett multiplikátor egy módositott változatát is közli.

A termelés importhányadának becslése meglehetösen reménytelen feladat, ezért egy viszonylag alacsony, legfeljebb $20 \%$ körüli arányt építhetünk be a modellezésbe.

A külföldi nyereségtranszfernek a becslése az egyetemek esetén egyszerü, hiszen a magyarországi állami egyetemek hazai tulajdonban vannak, a nyereség régióból való kiszívása nem értelmezhetö, legtöbbször azért sem, mert elvonható nyereség nem képzödik.

$\mathrm{Az}$ adókulcs meghatározása is több szempont megfontolását igényli. A modellel szemben az adórendszer összetett, nem csupán egyetlen lineáris adókulcsból áll. Az empirikus becslések általános megoldása, hogy két adókulccsal számol, egyrészt a személyi jövedelemadóval (átlagos adóterhet feltételezve), illetve az ÁFA-val (itt is átlagos kulccsal), feltételezve, hogy a fogyasztók adózott jövedelmük bizonyos hányadát költik el.

Látható, hogy az országos szinten becsülhető multiplikátornál, amely a magyar gazdaság sajátosságaival számol, és így bőségesen 1 alatti érték jellemzi, az egyetemek multiplikátora óvatos becslések szerint is 1 körül, de inkább kissé a fölött alakul.

\section{EMPIRIKUS EREDMÉNYEK}

Bár az elméleti háttér adott, a becslési módszereknek is létezik megvitatott irodalma (erröl ld. Siegfried et al, 2006), és számos külföldi empirikus példa is rendelkezésre áll (Caroll-Smith 2006, Blackwell et al 2002, Pallenbarg 2005, Jabalameli et al 2010, Tavoletti 2007, Huggins and Cook 1997, Bleaney et al 1992, Bridge 2005, Ohme 2003), mindössze egy befejezett esettanulmány lelhető fel a hazai szakirodalomban, a győri Széchenyi István 
Egyetem példája. $\mathrm{Az}$ ottani becslések 8-16 milliárd $\mathrm{Ft}$ közé teszik a hatást, annak függvényében, hogy milyen közvetett hatások kerültek figyelembe vételre, illetve milyen paraméter feltételezésekkel éltek. A Pécsi Tudományegyetemre is készültek számítások (Mezei, 2005), azonban a kutatásnak hatást számszerüsitő végeredménye nem ismert. Hasonlóan ismertek kezdeményezések Zalaegerszegen, de végeredményröl még nincsen hozzáférhető publikáció.

\section{5. ÖSSZEFOGLALÁS}

A tanulmányban levezettük azt, hogy milyen körülmények szükségesek ahhoz, hogy a gazdaság húzóágazatának számító export szektor miképpen képes a régió jövedelmeit elszivni, azzal szemben, ahogy a tankönyvi példák szerint megsokszorozza. A felsőoktatási intézmények helyi és regionális hatásainak feltérképezésére az elméleti modellek már évtizedes távlatban kidolgozásra kerültek. A tanulmányban ennek egyik változatát ismertettük, jelezve a számitásokhoz szükséges adatok forrását, megszerzési lehetôségét. Optimális lenne az az állapot, amikor többféle módszer szerint összehasonlító elemzések állnának rendelkezésre ez egyes intézmények hatásairól. Ez az állapot még messze van, de az oda vezetö út adott.

\section{IRODALOMJEGYZÉK}

Beck, R. - Elliott, D. - Meisel, J. - Wagner, M. (1995): Economic impact studies of regional public colleges and universities. Growth and Change, pp. 245-260.

Blackwell, M. - Cobb, S. - Weinberg, D. (2002): The Economic Impact of Educational Institutions: Issues and Methodology. Economic Development Quarterly, Vol 16, no 1, pp. 88-95.

Bleaney, M. F. - Binks, M. R. - Greenaway, D. - Reed, G. - Whynes, D. K. (1992): What does a university add to its local economy? Applied Economics, 24, pp. 305-311.

Bridge, M. (2005): Higher education economic impact studies: accurate measures of economic impact? Journal of College Teaching and Learning, 2, pp. 37-47.

Brown, K. H. - Heaney, M. T. (1997): A Note on Measuring the Economic Impact of Institutions of Higher Education. Research in Higher Education, vol 38, no 2, pp. 229-240.

Caroll, M. C. - Smith, B. W. (2006): Estimating the Economic Impact of Universities: The Case of Bowling Green State University. The Industrial Geographer, Vol 3, no 2, pp. 1-12.

Csávás, Cs. - Kóczán, G. - Varga, L. (2006): A föbb hazai pénzügyi piacok meghatározó szereplōi és jellemzō kereskedési stratégiái. MNB Tanulmányok 54. MNB, Budapest.

Dusek, T. (2003): A felsőoktatás lokális termelésre és jövedelmekre gyakorolt hatása. In: A Széchenyi István Egyetem hatása a régió fejlődésére. Szerk: Rechnitzer János-Hardi Tamás. Széchenyi István Egyetem Gazdaság- és Társadalomtudományi Intézet, Győr, pp. 60-71.

Florax R (1992): The university: a regional booster? Avebury, England

Garrido-Iserte, R. - Gallo-Rivera, M. T. (2010): The impact of the university upon local economy: three methods to estimate demand-side effects. Annals of Regional Science, 44, pp. 39-67.

Huggins, R. - Cooke, P. (1997): The economic impact of Cardiff University: innovation, learning and job generation. GeoJournal Vol. 41. no 4: pp. 325-337.

Jabalameli, F. - Ahrari, M. - Khandan, M. (2010): The Economic Impact of University of Tehran on the Tehran District Economy. European Journal of Social Sciences, vol 13, no 4, pp. 643-652.

Johnson, T. M. (1994): Estimating the Economic Impact of a College or University on a Nonlocal Economy. PhD dissertation, Texas Tech University, Texas.

Lengyel, I. - Rechnitzer, J. (2004): Regionális gazdaságtan, Dialóg-Campus, Pécs-Budapest.

Mezei, K. (2005): A Pécsi Tudományegyetem hatása a város gazdaságára. In: A magyar városok kulturális gazdasága. MTA Társadalomkutató Központ, Budapest.

Ohme, A. M. (2003): The Economic Impact of a University on Its Community and State Examining Trends Four Years Later. University of Delaware, mimeo. 
Pallenbarg, P. H. (2005): How to Calculate the Impact of University on the Regional Economy. Paper presented to the Conference on Knowledge and Regional Economic Development, Barcelona, 9-11 June 2005.

Robert, H. - Cooke, P. (1997): The economic impact of Cardiff University: innovation, learning and job generation. GeoJournal, vol 41, no 4, pp. 325-337.

Segarra i Blasco, A. (2004): La universitat com a instrument de dinamització socioconómica del territori. Coneixement i Societat, 03, pp. 78-101.

Siegfried, J. J. - Sanderson, A. R. - McHenry, P. (2006): The Economic Impact of Colleges and Universities. Vanderbuilt University Working Paper No. 06-W12. Nashville.

Tavoletti, E. (2007): Assessing the Regional Economic Impact of Higher Education Institutions: An Application to the University of Cardiff. Transition Studies Review, vol 14, no 3, pp. 507-522.

Thirlwall, A.P. (2002): The nature of Economic Growth. An alternative framework for understanding the performaces of nations. Edward Elgar Publishing, London. 